\title{
Ethical Aspects in Reality of Our Hotels Empirical Survey
}

\author{
Marek Merhaut \\ Institute of Hospitality Management in Prague, Czech
}

Copyright (C) 2015 Horizon Research Publishing All rights reserved.

\begin{abstract}
This paper reflects the results of a survey, conducted on a sample of approximately 100 employees of leading Czech hotels and international hotel chains in 2013. The inquiry was to analyze the role of ethics and code of ethics in the cultural policy of the hotel chains and tourism. Presented probe socio-cultural concerns in particular ethics of interpersonal relationships between workers of different nationalities, especially the Czech and foreign management staff, and then marginally etiquette rules as their reflection and individual expression. Author does not deny the fact that the rules of etiquette in the tourism and gastronomy, and that gradually changes between countries and cultures are significant differences that must be respected. But presents for discussion and reflection about their findings, as generally valid ethical principles and their instantiations in the rules adopted a code of ethics and respect in everyday practice hotel and hotel chain.
\end{abstract}

Keywords Ethics, Code of Ethics, Code of Ethics Rules, Etiquette, Internal Relations, Empirical Research, Corporate Culture, Respect

\section{Introduction: Concepts of Ethics, Etiquette and Code of Ethics and their Role in Society Ethics}

Although the definitions and interpretations of the concept of ethics in time and greatly varied civilizations, current definitions available online globalized world are relative to the details of the same. The question of course is whether they are also consistently interpreted and received. Will therefore not be considered as generally accepted, and the next it will be managed. Historically, all of the above meanings of the term ethics always intermingled. Here is an illustration of some of the concepts of ethics and ethical behavior that are the building blocks of today's seemingly "new" approaches. Overview of course not and cannot be (given the scope of the article), exhaustive.

For example, online business dictionary defines ethics as Ethics:

The Basic Concepts and Fundamental Principles of
Conduct human right It includes study of universal values such as Microsoft the essential equality of all men and women, human or natural rights, obedience to the law of land, concern for health and safety and, increasingly, also for the natural environment. "[1]

Other, sophisticated Web sites, however, distinguish basically three different understandings of the concept, which is English differ connection with the verb in the singular or plural:

Free dictionary [8] understands ethics as:

1.

a) A set of principles of right conduct.

b) A theory or a system of moral values: "An ethic of service is at war with a craving for gain" (Gregg Easterbrook).

2. Ethics (used with a sing. verb) The study of the general nature of morals and of the specific moral choices to be made by a person; moral philosophy.

3. Ethics (used with a sing. or pl. verb) the rules or standards governing the conduct of a person or the members of a profession: medical ethics.

Distribution by [7] and the other is similar:

1. The rules of conduct recognized in respect to a particular class of human actions or a particular group, culture, etc.:medical ethics; Christian ethics.

2. Moral principles, as of an individual: His ethics forbade betrayal of a confidence.

3. (Usually used with a singular verb) that branch of philosophy dealing with values relating to human conduct, with respect to the rightness and wrongness of certain actions and to the goodness and badness of the motives and ends of such actions.

Aristotle, in $4 \mathrm{Wed} \mathrm{BC}$, laid the ethical system to the level of "self-realization". According to him, a kind of imperative for every person "to act in accordance with His nature and HIS develop latent talents in order to be content and complete. Lucky individual was seen as the ultimate goal. Some authors of Aristotle's conception of morality write: "Things, dry and civic life or wealth, are Merel Means to the end. Self-Realization, the awareness of one's nature and the development of one's talents, is the surest path to happiness and Ethical behavior".[2]

In contrast, the traditional Chinese concept of ethics, the 
Mohist consequentialism is based on the "good for all". This ethical theory especially appreciates the "moral worth of an action based on how much it contributes to the social harmony of a state. Stanford Encyclopedia of Philosophy describes "Mohist consequentialism," which dates from about the same time as philosophy Aristotle (about 5 Wed $\mathrm{BC})$ as "a remarkably sophisticated version based on a plurality of intrinsic goods Taken as constitutive of human welfare.“.... . "The basic goods in Mohist consequentialist thinking are ... order, material wealth, and Increase in population". [6]

Kant's conception of morality and his categorical imperative is so well known that it probably is not necessary to describe them, let us therefore only mention (by [3]): „Kant argues that to act in the morally right way, people must act from duty, and that it was not the consequences of actions that make them right or wrong but the motives of the person who carries out the action. Something is 'good in itself' when it is intrinsically good and 'good without qualification when the addition of that thing never makes a situation ethically worse. Kant then argues that those things that are usually thought to be good, such as intelligence, perseverance and pleasure, fail to be either intrinsically good or good without qualification. Pleasure, for example, appears to not be good without qualification, because when people take pleasure in watching someone suffering; this seems to make the situation ethically worse. He concludes that there is only one thing that is truly good: Nothing in the world-indeed nothing even beyond the world-can possibly be conceived which could be called good without qualification except a good will. " [3]

Pragmatic ethics first half of the 20th century, been associated especially with the names of Charles Sanders

Peirce, William James, John Dewey and, in particular, gives moral correctness in context with science (especially economics and sociology), and it also makes them.

The current Australian philosopher Peter Singer defines rather concentrates on what is ethical. According to Singer, is nothing ethical about what moral code is just for a certain group? For example, "it has nothing to with a set of prohibitions Concerned with sex lain down by a religious order. Neither is ethics and "That system is noble in theory but no good in practice." Singer agrees that ethics is somehow universal, but "in a Utilitarian way it affords the" best Consequences "and furthers the Interests of Those affected."

Modern philosophy regarding the notion of ethics seems to be rather confused and unfortunately nope not in line with current neuroscience, genetics, evolutionary biology and other exact sciences, which in the last decade have made unexpected knowledge. Let us only note that the current neuroscience, and knowledge mediated functional imaging methods, such as studies Canadian psychiatrist and neurophysiologist R. Hare on "psychopathic mental diseases", as well as the findings made by the genetics of reading the human genome in 2000 , brings notion of ethics, new moments (see the observations of Dr. Mark Vache, head of the Institute of ethics 3rd Medical Faculty, priest and molecular biologist). They however, if the truth rather Aristotle than Kant and his followers, is still difficult to assess. [4], [5]

Understanding of ethics as rules of conduct, binding to a particular group (usually in relation to the profession) reflects the ethical codes that play or should play an increasing role in the life of modern man.

\section{Etiquette:}

With some simplification we can say that a reflection of ethics in everyday practical life is a set of generally respected practice in interpersonal contacts, which we call the label. Etiquette is a set in a given space and time correct forms and habits of social intercourse and behavior, in other words, the application of interpersonal relationships in practice. Conduct and behavior in society or social group presupposes and requires a generally accepted and respected by the order, which is further specified certain rulestransmitted upbringing.

The constant changes in society inevitably also lead to the development and changes in labels. This motivation level sensory-empirical beyond (transcend) and is based on the so-called pure reason, which is not influenced by sensually. Introduces the concept of the categorical imperative as an act of rational motivation nature of each rational beings - that generally human. If there is a motivation negotiation of pure reason, then, according to Kant, must also respond well clear purpose - the highest good. Each individual should act to the moral principles of his will to become universal law of conduct throughout the company. [3]

\section{Code of Ethics:}

Code of Ethics is a document that provides general and specific rules of work in different organizations and professions. Our Code of Ethics for example, is doctors (Hippocratic Oath), lawyers, journalists and many other professions. Also, some organizations, associations or companies can generate code for their employees, either mandatory (an employee can get the code for the signing of the contract and on the basis of violation under threat of dismissal) or voluntary (which compliance is voluntary).

Fixed codes of ethics on the one hand facilitate subsequent monitoring compliance and thus achieve the desired positive outcome. On the other hand, it is well formulated rules, which are based on the desire to discriminate against anyone or anybody favoring. They can therefore sometimes only lead to passive buck-passing negotiations under the rules generally without trying to find new and original while legal solutions.

Company culture - the corporate culture with its values and standards is characterized by a certain superficial symbolism and can be organized as a set of expressions of the conduct and behavior of owners, managers and other employees, i.e., As a behavioral manifestation of corporate culture in the form of rituals and ceremonies, communication patterns and styles, maintained traditions and customs, ways 
of rewarding and punishing, attitudes to the environment, customers, complaints, external communication in the form of verbal abuse, such as myths, heroes, names, metaphors, jargon used - overt manifestations of corporate culture, such as the name company emblem (logo) of the company, its brands, promotional and advertising materials, corporate clothing and uniforms. In the case of corporate culture (corporate culture) is a systematic creation of favorable conditions for the activities of employees in the company and for the successful operation of the company in its business environment. Since the company's culture is generally expected to contribute to the effective functioning of the company and its long-term prosperity and development.

Corporate culture - essentially determines what the firm considered helpful, what ways this can be achieved and what are the impulses for initiating change. It is important to note that the corporate culture, there is always independent of our will, and it is a concept describing the properties of a social system. Corporate culture is homogeneous, coherent complex internal company factors and conditions substantially affect the operation, performance, success and development.

\section{Objective}

a) The aim of the investigation was to determine to what extent the company code of ethics adhered to in relation to the foreign owners of Czech employees. In this article I will focus only on the issue of the use of the code of ethics in practice, which has been under investigation conducted by authors of the article, by the end of 2013, the group of 12 hotel chains hotels in Prague, a questionnaire, supplemented in some cases directed interview. Total of 50 employees were interviewed these devices, and 15 other leaders (representatives of the hotel).

b) The aim of the field research was a basic orientation in the way of applying the principles of ethics in business hotel chains, namely verification and to determine whether and how the elements are processed in corporate ethics papers as vetted done on this subject and how training is evaluated compliance with ethics and etiquette.

c) Another aim of the empirical investigation was to find out what are the internal relations in various hotel facilities, with an emphasis on personal relationships between the foreign management and Czech employees.

\section{Methodology}

For empirical investigation the following techniques were used: questionnaire, interview and direct observation.

To verify the accuracy of selected questions in the questionnaire and interviews, to refine, clarify and assess clarity of tasks designated to serve piloting testing, conducted in a group of thirty respondents selected and has long monitored hotel facilities. Pilot confirmed that the proposed research is to understand the tool and provides differentiated testimony, and that the selected data collection strategy can be implemented. Among piloting his own investigation and was left interval of one month and was then conducted its own investigation, which was repeated once more with the passage of the next six months to a similar group of respondents.

The result was profiling a relatively small finite set of respondents with whom contact was established. These then became the subject of further investigation in the form of structured interviews and observations. Data obtained through the questionnaire and other methods were then compared and further processed by different methods.

\section{Selection of the sample of respondents:}

When selecting the sample hotels was due to the sensitivity of the issue of improbable used selection method namely "snow ball sampling". This method came to my hotel facilities such as the following:

Falkensteiner Hotel Maria Prag (string Falkensteiner Hotels \& Resorts), Parkhotel Praha (SG Group), Corinthia, Corinthia Panorama, Ibis Praha Karlin, Prague City Ibis, Novotel, Mercure, Ibis Praha City Centre, Ibis Praha Old Town (chain Accor), Pyramid Hotel Prague (string Orea Hotels) and more.

\section{Collecting data in the form of questionnaires:}

The questionnaire contained 25 questions and was divided into the following parts:

Part I. Identification information about the queried entity empirical investigation

Part II. Company code of ethics - an empirical survey questions

Part III. Employee relations - questions of empirical investigation

Part IV. Individual interviewer findings of an empirical investigation

When creating a questionnaire I used mainly comparative questions that allowed me to analytical and synthetic view of the elements examined perceptions of hotel codes of conduct and their qualitatively different function, but also accurate mutual comparison of these elements using a numeric expression scoring system (1-100).

If used, the scale was a Likert-type scale. Unfortunately, I did not include semantic differential which would help some sensitive questions better structured and evaluated.

The first three questions of empirical questionnaire included identification of the surveyed business entity and are intended solely for the needs of the interviewer. The following ten questions focused on the company's code of ethics. Five questions were focused on the issue of inter-personal relations, one question then internal staff training and professional functionality works councils in the hotel environment. The last five items no questions in the true sense of the word. It was more of a controlled recording 
of the interview, completed by the interviewer in this case. The location at the end of each questionnaire then facilitates comparison. In designing the questions, we had to reconcile often conflicting objectives and intentions.

Questionnaires were distributed to end-respondents in printed form because of the validity of Internet questionnaires or questionnaires sent by mail, there are very serious doubts. The hotel management about them has always been informed in advance, and it is available, despite these measures, aimed at transparency and "legalization" of the event at the end of the respondents showed considerable shyness. Especially since questionnaires were designed as an anonymous, in respondents, however, was investigated age, education and job placement. This anonymity has only imaginary and respondents were aware. The more important was the personal (driven) interview, which in some cases broke the ice.

\section{For data collection was designed method guided interview}

For data collection was designed method guided interview, included in the first phase of training interviewers and respondent's selection. The actual interview was directed at the first stage to the "breaking of distrust", clarifying the importance of research, a promise of confidentiality and anonymity. In the second stage, the goal was to get the most openly and honestly, to maintain interest while the interviewee not to exceed 60 minutes total time. If the interviewee has given consent to the recording, was recorded as an acoustic record that when processing data from a controlled interview helps prevent misrepresentation and misunderstanding.

\section{Collecting data through the observation:}

Collecting data through the observation did not include the preparation and training of observers, because of the relatively small size of the sample was made by one person. Took place mainly in the preparatory phase prior to the survey and are in the process of making contacts.

\section{Results}

Conducted surveys, subsequent analysis and comparison between the response and processing notes and suggestions gathered during personal meetings with managers of hotels has produced a large amount of information. One of the ways to use the information gathered is to try to identify some areas where it would be desirable to improve the existing condition.

\section{Level of acceptance:}

Before the questionnaire is distributed empirical investigation in the phase where the interviewer and observer future respondents familiar with the meaning and purpose of the investigation, the atmosphere was friendly (whether sincerely or out of a sense of duty) in about $58 \%$ of managers. Conversely, the complete rejection occurred only at $15 \%$.
Positive reception - friendly atmosphere with a genuine interest - $18 \%$ of respondents

Friendly atmosphere, but the adoption of the requirement $40 \%$ of respondents

Adoption neutral - unwillingness to comply with the subsequent fear of the potential consequences of the hotel management - $27 \%$ of respondents'

Refusal to participate in the investigation - $15 \%$ of respondents

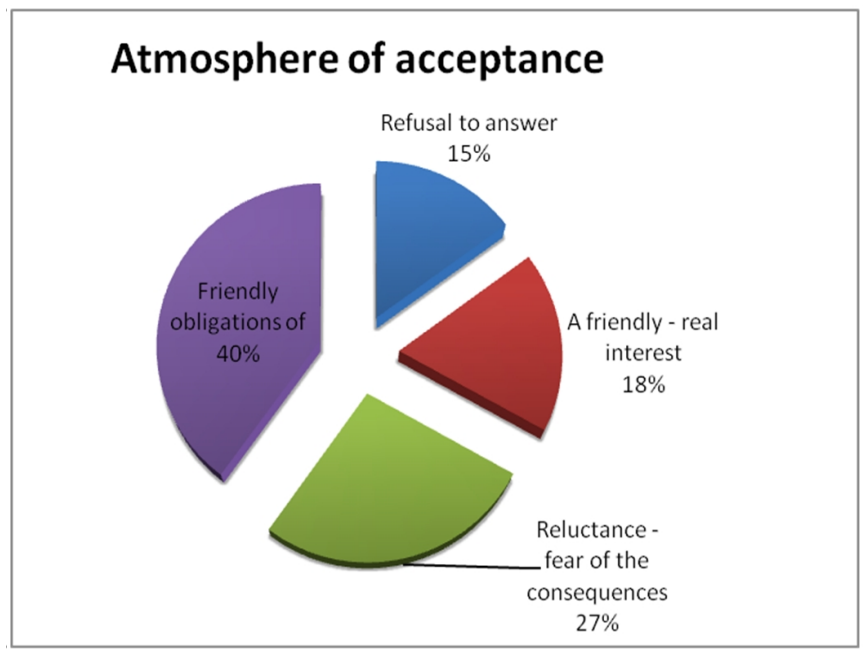

Graph 1. Atmosphere adoption questionnaire before the start of an empirical investigation

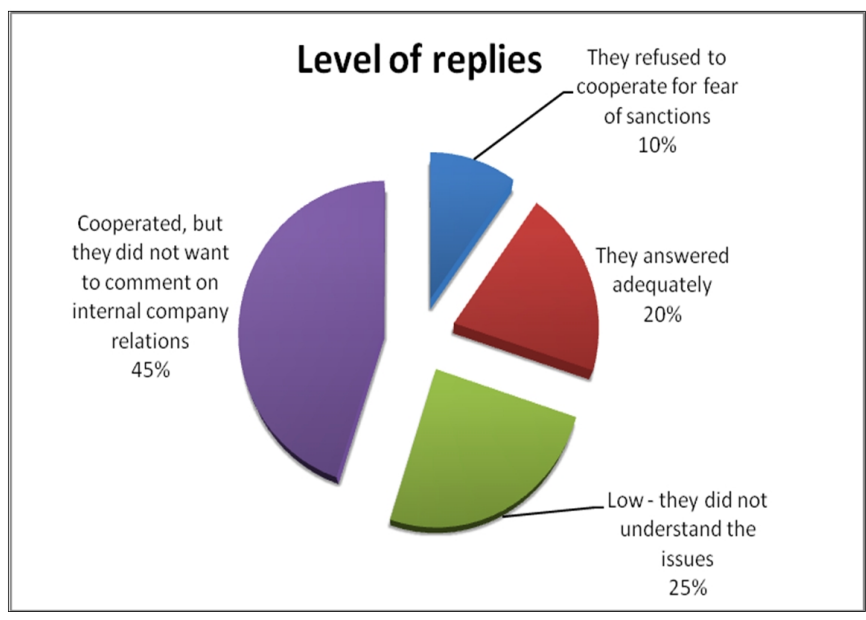

Graph 2. Level of respondents' answers

The level of response (in terms of understanding and willingness to respond)

Only $20 \%$ of respondents answered all the questions and expressed full understanding of the formulation. $45 \%$ of respondents expressed their understanding and comprehension formulations, but refused to answer the part of the questions related to intercompany relationships. In about $25 \%$ was apparent misunderstanding of the issues and $10 \%$ of respondents (especially among young and novice Management) cooperation rejected outright. 


\section{The results of observations and guided interview:}

The results of observations and guided interview are more complicated, but for the purposes of this publication we summarize in the following overview.

High level responses of respondents $-25 \%$ of respondents, Positive answers $-28 \%$ sufficient responses - 15\% partial responses of respondents - 17\% Lack of answers of respondents - 10\% Negative impression - totally inadequate response to the subsequent refusal of respondents - 5\%

\section{Personal impression of the interviewer from the questionnaire survey of respondents}

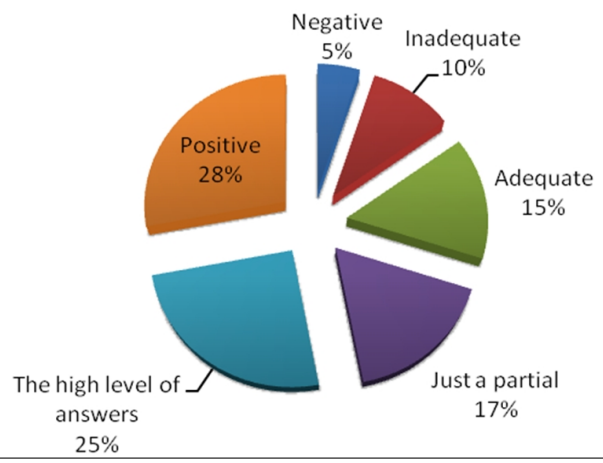

Graph 3. Personal perception of the interviewer questionnaire survey, the respondents

\section{Level of application of general ethical standards}

A somewhat different situation is in the application of ethical standards and principles. Responses indicate shortcomings, which in many cases cannot be considered negligible.

As at least, problematic can mark the following areas: relations to competition, employee evaluation (selection of new employees, preference, compensation, promotion) and the associated potential discrimination of certain groups and individuals.

Propose specific measures that would positively affect the current, very delectable situation is not easy. Surely it is possible to add and edit corporate documents, regulations and guidelines as required. However, this is only the formal side of things. Real internal adoption of ethical standards and especially courage against possible unethical conduct exit, but it is another matter.

\section{Behavior management level foreign employees against Czech}

According to the survey results can be stated that in relation to the Czech employees with foreign managers often behave as an arrogant manner. They give them in this way show their superiority.

This was reflected in the questionnaires, but especially in a controlled interview and observation mainly. In some cases, a foreign tops of Management evident unprofessionalism, ignorance of the cultural environment of our country and not least the language barrier. All this is then reflected in unnecessarily and unreasonably gross behavior, which in the eyes of our employees' leadership abroad reduces not only professionally, but also on a human level. Experiences and feelings of Czech respondents (in this case, a particular department head, therefore, not employees) very well reflected in the charts below and in them the values.

\section{Conclusions}

Not very pleasing results of the investigation lead to the following conclusions:

It is necessary to reject the widespread view that the Code of Ethics is a product imported from a different cultural environment and its implementation is a kind of fashionable wool.

At the same time I find it useful to understand the stop code of ethics as unchanging theoretical document, but instead of him to make a living instrument, with which the company operates, which is assessed and updated.

As is evident from the graphs that are based on the results of structured interviews with respondents who were recruited from the ranks of senior management, i.e. from the ranks of heads of departments surveyed hotel facilities, we can talk about the level of application of existing regulations for employee evaluation is least problematic.

I believe that the code of ethics should reflect the cultural environment and habits host nation.

The positive results of investigations on the contrary are the fact that the analysis of responses essentially confirmed the expected high level of etiquette in hotel operation, particularly in relation staff - client (host. It is obvious that it is a traditional part of the hotel standards. It is hard to imagine without friendly hospitality cultural, cordial and friendly atmosphere.

This complex includes the company's values, norms, practices and behaviors, corporate ethics and etiquette, patterns, myths, rituals and ceremonies, the level of maturity of the instruments of labor, methods and practices of organization and management, access to employees, superficial attributes of the company and its work towards business partners, customers, and the public. Non-public set of rules in tourism parlance called the hotel corporate culture or the culture of the hotel chain.

Hotel chains have introduced this name jargon management documents and rules and implement them into your "know - how". Today these rules, hotel chains and other devices in tourism clearly manage and transmit this message to your employees as corporate culture, social conformity and uniformity. I can certainly imagine all physician behavior that would be on the edge of the code of ethics, or even beyond. Comply but also other groups of employers and employees or their ethical codes? Or brush up on their edge? They know all about them and accept them as our own? These and similar questions should answer my survey. 


\section{Warning}

Story, theoretical part, the methodology and its own investigation: PhDr. Marek Merhaut, Ph.D., MBA - Head of Department of Hospitality, Institute of Hospitality Management in Prague 8 (merhaut@vsh.cz).

\section{REFERENCES}

[1] http://www.businessdictionary.com/definition/ethics.html\#ix zz1o8M7A5ez

[2] http://en.wikipedia.org/wiki/Ethics\#Greek_philosophy

[3] KANT, IMMANUEL. 'First Section: Transition from the Common Rational Knowledge of Morals to the Philosophical', Groundwork of the Metaphysic of Morals. 1785.

[4] CLECKLEY, H. The mask of sanity. Wiliam and Dolan. New York. 1988.

[5] HARE, R. Psychopatic mental disorder, available at http://www.cassiopaea.com/cassiopaea/psychopath.htm

[6] LOEWE, M. -SHAUGHNESSY, E. L. The Cambridge History of Ancient China. Cambridge University Press. p. 761.1999 .

[7] http://dictionary.reference.com/browse/ethics

[8] http://www.thefreedictionary.com/ethics

[9] ANZENBACHER, A. Úvod do etiky. Praha: Academia, 2001. (Introduction to Ethics. Prague: Academia, 2001)

[10] ASSMAN, J. Kultura a pamět’. Praha: Prostor, 2001. (Culture and memory. Prague: Space 2001)
[11] BERÁNEK, J., Kotek, P. Řizeni hotelového provozu. Praha: Grada Publishing, 1998. (Management of hotel operations. Praha: Grada Publishing, 1998.)

[12] BERGSON, H.: Dva zdroje morálky a náboženství. Praha: Nakladatelství Vyšehrad, 2007. (Two Sources of Morality and Religion. Praha: Vyšehrad Publishing, 2007.)

[13] BLACKMOREOVÁ, S. Teorie, kultura a jeji evoluce. Praha: 2001. (Theory, culture and they evolution. Praha: 2001).

[14] BLÁHA, I., A. Etika jako věda. Brno: Atlantis, 1990. (Ethics as a science. Brno: Atlantis, 1990).

[15] GELLNER, E. Rozum a kultura. Brno: CDK, 1999. (Sense and culture. Brno: CDK, 1999)

[16] HABÁŇ, M. Přirozená etika. Praha: TRS, 1991. (Natural ethics. Prague: TRS, 1991)

[17] HOFSTEDE, G. Kultury a organizace. Praha: 1999. (Organization and culture. Prague: 1999)

[18] DAMASIO A. R. Descartesưv omyl, Emoce, rozum a lidský mozek, Praha: Mladá fronta, 2000. (Descartes mistake, Emotion, Reason and the Human Brain, Praha: Mladá fronta, 2000)

[19] NOVÝ, I., SCHOOL, E., Machl, S. a kol. Interkulturálni komunikace v ř́zení a podnikání. Praha: Management Press, 2001. (Intercultural communication in management and entrepreneurship. Praha: Management Press, 2001)

[20] HOŠKOVÁ, M. Modely osobnosti S. Freuda a E. Ericksona, 22. - 23. 2. 2008 (Personality models S. Freud and E. Erickson).

[21] KLÍMOVÁ, H. Člověk jako skupina a emoce ve skupině, 23. -24. 5. 2008 (Man as a group and emotions in a group).

[22] SMOLÍKOVÁ, M. Strukturální politika a kultura. Praha: 2005. (Structural policy and culture. Praha: 2005). 